\title{
Impact of government balance and exchange rate regime on current account during the economic cycle: evidence from CEE countries ${ }^{* 1}$
}

\author{
Zoran Grubišićc ${ }^{2}$, Sandra Kamenković ${ }^{3}$, Aleksandar Zdravković ${ }^{4}$
}

\begin{abstract}
The key goal of this research is to empirically determine whether the fiscal policy and the choice of exchange rate regime played significant role in current account determination in 16 CEE countries, with respect to large cyclical fluctuations of economic activity in the period 1999 - 2012. The methodology is based on the panel estimation of the impact of exchange rate regimes and government balance, being the key explanatory variables, on current account balance. The main results show that contrary to the "twin deficit" hypothesis government balance had nonsignificant and negative association with current account. On the other hand, fixed exchange rate regime contributed to the accumulation of current deficits, especially during the boom years. The results of the estimation are robust to the different model specifications and estimation methods applied. It is indicated that divergence between current and government balance is associated with the fluctuations of the economic activity, since the increase in government revenues
\end{abstract}

\footnotetext{
* Received: 20-06-2017; accepted: 26-03-2018

1 This Paper is a part of research projects No. III47009, European Integrations and Socioeconomic Changes in the Economy of Serbia on the Way to the EU, project manager Professor Božo Drašković and OI179015, Challenges and Prospects of Structural Changes in Serbia: Strategic Directions of Economic Development and Harmonization with the EU Requirements, project manager Professor Ivan Stošić, financed by the Ministry of Education, Science and Technological Development of the Republic of Serbia.

2 Full Professor, PhD. Scientific affiliation: international finance, macroeconomics. Belgrade Banking Academy, Zmaj Jovina 12, Belgrade. Phone: +381 112621 730. E-mail: zoran. grubisic@bba.edu.rs.

${ }^{3}$ Assistant Professor, PhD. Scientific affiliation: macroeconomics, public finance. Belgrade Banking Academy, Zmaj Jovina 12, Belgrade. Phone: +381 112621 730. E-mail: sandra. kamenkovic@bba.edu.rs.

${ }^{4}$ Research Assistant, MA. Scientific affiliation: macroeconomics, public finance. Institute of Economic Sciences, Zmaj Jovina 12, Belgrade. Phone: +381 112623 055. E-mail: aleksandar. zdravkovic@ien.bg.ac.rs
} 


\begin{abstract}
during the good years reduced deficits despite pro-cyclical fiscal policy. Also, it has been argued that in the period prior to the crisis, in the countries pursuing fixed regimes current deficit was accumulated at higher pace when compared to countries with floating regimes, despite appreciation pressures deriving from the large inflow of foreign capital. Based on the results of empirical analysis, the recommendations on benefits of floating regimes are given to policy makers in CEE countries.
\end{abstract}

Key words: twin deficit, exchange rate regime, current account, CEE, panel analysis

JEL classification: F32, C23, E32, E62

\title{
1. Introduction
}

The determinants of current account have been the subject of long-lasting debates and controversies among economists, because findings of the empirical works tend to differ with respect to sample of countries, periods and underlying methodologies. While growing literature expands the empirical analysis to encompass possible impact of numerous macroeconomic variables of the secondary importance, the government (fiscal) balance and exchange rate regime are traditionally considered to be among the key determinants affecting current account adjustments and external stability.

The most frequently cited theoretical framework explaining transmission mechanism of the fiscal balance on current account is known as the "twin deficit" hypothesis (TDH). The "twin deficits" hypothesis claims that a reduction in the fiscal deficit causes a reduction in current account deficit. Keynesian incomeexpenditure approach simply explains the functioning mechanism of the twin deficits. The analogy implies that an increase in fiscal deficits, leads to increased domestic absorption, increasing domestic income. That increase induces imports, which will cause increase of deficit or reduce of suficit in the trade balance. In the case of an open economy with high capital mobility, the increase in the fiscal deficit leads to an increase in aggregate demand and domestic real interest rates, which consequently encourages the net inflow of capital from abroad and the domestic currency appreciates. The higher value of the local currency discourages net exports, which worsens the current account (Akbostancı and Tunç, 2002).

The empirical evidence on covariations between fiscal and current balance mostly support the TDH (Chinn and Prasad, 2003, Bussiere et al., 2004, Chinn and Ito, 2007), yet some papers claim occurrences of "twin divergence". Kim and Roubini (2008) were among the first who find empirical evidence in support of twin divergence, analyzing the historical data for US for the period of flexible exchange rate regime. Nevertheless, they recognized that none of the existing theoretical models, including those suggesting that budget deficit shocks might improve current account, is capable to fully explain results from their study. The twin divergence is 
also found in some other studies, both for advanced (Corsetti and Müller, 2006) and emerging economies (Van Bon, 2014, Obadić et al., 2014).

While government balance is considered to be the current account driver, exchange rate regime represents transmission mechanism per se determining how the current account adjusts to the macroeconomic imbalances or changes in economic policy. As an advantage of flexible exchange rate regimes authors highlight their effectiveness in correcting the balance of payments imbalances. Simultaneosly, if the country achieve external balance automatically and without difficulty, achivement of internal equilibrium is facilitated. On the other hand, flexible exchange rate regimes are related with degree of uncertainty, causing a decrease of volume of international trade and investment (Domac et al., 2001).

The recent global crisis and surrounding economic fluctuations revived the discussion about intertwining of macroeconomic variables conditional on the phases of economic cycle. Some of the papers dealing with current account determinants aspire to capture effects of cyclicality on current account adjustments. Using a large panel of 94 countries from 1973 to 2008, Cheung et al. (2010) found that the medium-term evolution of global external imbalances can be related to a great deal to structural factors, but since the financial crisis current account adjustments appear to be related to various cyclical factors. Haltmaier (2014) quantifies a cyclical portion of the current account balance for 35 countries, and finds that cyclical factors account for 10 to 30 percent of the imbalances reduction. Similar results are obtained for the EU countries, wherein cyclical factors explain less than half of the current account adjustment between 2008 and 2012 with the notable exception of Greece (European Commission, 2014). The issue of cyclicality in current account movements is especially important subject in Central and Eastern European (CEE) economies. As a matter of fact, economies have experienced large cyclical fluctuations during the recent period. The large inflows of the foreign capital, either through credit expansions of the banks or foreign direct investment, created structural imbalances in external sector which reflects in excessive values of current deficits and increase in foreign debt. As Rahman (2008) points out, 10 new EU member states run considerably higher current account deficit relative to other developing countries in the 15-year period prior to crisis, as the consequence of the foreign-financed investment boom. Since the global crisis has diminished inflow of the foreign capital, CEE countries strive to adjust current accounts and reduce external vulnerability. Zdravković et al. (2014) illustrate the sharp reduction in current account deficits in CEE countries during the post-crisis period.

Against this background, the issues of "twin deficit" hypothesis and the choice of exchange rate regime on external stability in CEE countries are analyzed. We tested two main hypotheses: whether the fiscal balance and current account balance moved into the same direction and whether flexible exchange rate regimes were beneficial for current account adjustments, both in the presence of large economic 
fluctuations. The analysis is based on the panel estimation of the impact of exchange rate regimes and government balance, being the key explanatory variables, on current account balance for $16 \mathrm{CEE}$ countries ${ }^{5}$.

The paper is organized as follows: in the first section, a comprehensive overview of the empirical work on current account determinants is presented with particular focus on government balance and exchange rate regimes. In the methodology section, the development of the empirical model is explained grounded on basic macroeconomic identity. In the third section, data is depicted, along with the issues of econometric estimation and outputs of empirical analysis. The last section discusses empirical results and underlying explanations. Eventually, findings of the study are summarized, as well as policy implications and prospective of the future research.

\section{Literature review}

The current account balance is considered to be one of the most important economic stability indicators of open economies. Large and constant current account deficits are potential generators of economic crises, especially if they are caused by structural internal imbalances or if they coincide with large exogenous shocks. For this reason, the analysis of the current account determinants is the subject of numerous empirical and econometric studies, most commonly at panel level, but also at the level of individual countries. The benefit of the panel regression analysis of the current account determinants derives from the generalization and robustness of the results obtained based on the processing of a large number of observations, which is particularly significant in the analysis of emerging and developing countries where often there are no long time series of annual data. On the other hand, analysis of individual countries enables the use of more flexible and complex models and methods, as well as focusing on more concrete research issues in determining the current account balance.

The intertwining between the fiscal policy and current account has been the long-lasted subject of empirical research, since the early econometric studies on current account determination. The most important and oldest study of this kind is Debelle and Faruque (1996), which analyzed the short-term and long-term effects of the selected economic and demographic variables on current account balance movements, using data for 21 industrialized countries in the period 19711993. The analysis of the short-term effects of fiscal policy has shown a positive impact of the fiscal balance on the current account balance ( 0.16 percentage

\footnotetext{
5 The sample contains the following 16 countries: Albania, Bosnia and Herzegovina, Bulgaria, Croatia, Czech Republic, Estonia, Hungary, Latvia, Lithuania, Macedonia, Montenegro, Poland, Romania, Serbia, Slovak Republic and Slovenia.
} 
points for the unit change in fiscal balance), while the long-term effects were contradictory depending on the methodological approach (cross-section vs. panel approach). Debelle and Faruque connected the absence of the impact of fiscal policy based on the cross-section analysis with the possible positive response of the investments on the increase in the fiscal balance, offsetting the effect on the current account. Yet, inclusion of the country-specific effects in the panel regression restores positive impact. Chinn and Prasad (2003) study directly complement the work of Debelle and Faruque (1996); the authors expanded the sample to include 71 develpoing countries, and shifted the focus on medium-term current account balance determinants using five-year non-overlaping periods as panel analysis timeframes. From the point of view of the fiscal policy, the most important findings in their panel study indicate the absence of fiscal balance impact on the current account in industrialized countries, while in the case of developing countries this effect is notable - the unit increase in fiscal balance resulted in the increase of current account balance for 0.4 percentage points. The authors have pointed out the incomplete Ricardian's offset of changes in public saving as a possible explanation of this result in developing countries.

Empirical evidence on the impact of fiscal balance on current account in the early studies of Debelle and Faruque (1996) and Chinn and Prasad (2003) were in contrast with theoretical intertemporal models of current account assuming representative agents that optimize Ricardian behavior, thus implying irrelevancy of fiscal policy. In order to bridge the gap between stylized facts and theoretical work, Bussiere et al., (2004) relaxed assumption of representative Ricardian agent and developed dynamic model of current account which formalizes impact of fiscal policy, in line with twin deficits idea. The results of their empirical analysis on the sample of OECD and EU accession countries have confirmed the expectations of the positive impact of the fiscal balance on the current account balance and the assumption that the Ricardian equivalence does not fully apply. However, major conclusion from their empirical study that high current account deficits in EU accession countries are approved by the underlying fundamentals may be considered as controversial from the standpoint of after-crisis economic development. The other notable studies that follow this strand of research include Chinn and Ito (2007) and Ca'Zorzi et al. (2012). Chinn and Ito (2007) extend the work of Chinn and Prasad (2003) to encompass possible effects of legal and institutional developments on current account dynamics. They found out that positive impact of fiscal balance on current account balance remains robust even when controlled for legal and institutional developments. Ca'Zorzi et al. (2012) aspire to draw robust conclusions on current account determinants combining permutation of 14 potential explanatory variables with three different econometric strategies of modelling. While fiscal balance is not confirmed being fundamental in each of their selected "optimal" models, its positive effect on current account balance is not challenged. Instead of analyzing continuous response of current account to overall or primary balance, Bluedorn and 
Leigh (2011) investigate how current account balance reacts to fiscal consolidation policy actions being strictly motivated by budget deficit reduction. Based on analysis of 17 OECD countries over the period 1978-2009, they conclude that twin deficit behavior is particularly pronounced in the periods of fiscal consolidation, as unit reduction in fiscal deficit raises the current account balance-to-GDP ratio around 0.6 percentage points.

Eventually, it can be underlined that notable empirical studies based on large panels of industrialized and emerging/developing countries almost uniformly provide evidence in support of the TDH. An exemption is a study of Forte and Magazzino (2015), who applied great variety of panel estimation techniques (static and dynamic panel estimations, common correlated effects mean-group estimation, finite mixture model estimations) to the sample of Eurozone countries for the period 1970-2010. Findings of their study tend to differ across estimations and do not provide clear evidence neither in favour nor rejection of the TDH. The other example is a study of Aristovnik (2013), whose findings reject the TDH for the full sample of EU countries, as well as for both subsamples of the old and new EU member states. He concludes that rejection of TDH indicates high level of capital mobility in both regions, in line with Feldstein and Horioka puzzle on low correlation between domestic investments and savings.

Nevertheless, not all of the empirical studies confirmed positive and significant relation between fiscal and current account balance. Bussiere et al. (2004) listed the results from twelve empirical works analyzing response of current account to fiscal policy in advanced countries; four studies found no response, and study of Kim and Roubini (2008) even found a reverse response. The lack of response or reverse response is rather found in studies that examines fiscal balance shocks to current account than in OLS-wise panel studies. Since the Blanchard and Perotti (2002) milestone work, use of structural VAR models to control endogenous feedbacks among variables has gained in popularity as a framework for fiscal policy analysis. The cyclical reactions of current and fiscal balance in opposite directions are often citied in favor of structural approach. As underlined by Corsetti and Müller (2006), current account tends to react counter-cyclical, opposite to pro-cyclical reaction of fiscal balance, which induces negative correlation between these variables over the economic cycle. Thus, analysis of current account response to exogenous fiscal shocks is expected to provide more reliable estimates of this relation.

Kim and Roubini (2008) analyzed the effects of government deficit shocks on the current account and the real exchange rate in the US using structural VAR. Their basic empirical result indicates that government deficit shocks improve current account and depreciate the real exchange rate, at least in a short run, contradicting the predictions of standard theoretical models. They point out that twin divergence may be natural outcome of a productivity shock, as the follow-up investment boom tends to aggravate current and improve fiscal balance. However, the divergence 
remains robust even after controlled for endogenous feedback of current and fiscal balance to economic cyclicality and productivity shocks. To explain this empirical puzzle, they extended analysis to the government budget components and shows that twin divergence is stemming from the combination of crowding out effect caused by an increase in the real interest rate and partial Ricardian reaction of private savings. Corsetti and Müller (2006) discuss the relevance of openness and fiscal shock persistence in transmission of fiscal policy to current account, applying Kim and Roubini (2008) approach to analyze data for the US, the UK, Australia and Canada. Empirical evidences support their hypothesis that external effects of fiscal policy is limited in more closed economies with less persistent spending shocks, such as US and Australia, because of the substantial crowding of private investment. Nickel and Tudyka (2014) found that level of public indebtedness can be transmission channel that turns the twin deficit to twin divergence relationship, because private sector tends to internalize the government budget constraint following the rising debt-to-GDP ratio. Based on the panel VAR estimation for a sample of 17 European countries from 1970 to 2010, they provide evidences that trade balance reacts in the same direction as the fiscal stimuli when debt-to-GDP is low, but switches to divergence as the public indebtedness increases. Bussiere et al. (2004) also fail to find robust relation between government balance and current account dynamics for 21 OECD countries. Instead of structural VAR, they use parsimonious model where changes in the real current account are explained by the productivity shocks and cyclically-adjusted primary balance. While the impact of productivity shocks turned to be large, impact of fiscal balance, as they conclude, seems to be either non-existing or not sufficiently stable. Evidences on "wrong" causality direction of fiscal policy to current account are also found in empirical studies dealing with less developed economies, like in Van Bon (2014) for ten Asian developing (panel GMM and panel error-correction) or Obadić et al. (2014) for four European emerging economies (structural VAR).

While theoretical considerations and empirical evidences on the role of fiscal policy in current account dynamics are mixed, "it is often asserted that a flexible exchange rate regime would facilitate current account adjustment" (Chinn and Wei, 2013). This opinion is theoretically rooted since the early fifties following the famous work of Friedman (1953), yet empirical data on macroeconomic performance of floating regimes were scarce due to the Bretton Woods system. After the fall of the Bretton Woods system, a gradual cummulation of statistical data over the next 30 years provided solid grounds for empirical analysis on the role of fixed and floating regimes in current account adjustments. The major issue to conduct such sort of analysis was proper classification of exchange rate regimes. Studies like Ghosh et al. (1997), Frankel (1999) and Calvo and Reinhart (2002) notice the mismatch between de jure (appointed by the IMF until 1999 according to officially declared exchange rate policy) and de facto regimes in some countries. The newly proposed classification schemes of exchange rate regimes in Ghosh et al. (2002), Reinhart 
and Rogoff (2004) or Levy-Yeyati and Sturzenegger (2005) provide improved databases for empirical examination of the macroeconomic relations with respect to exchange rate policy.

Most of the empirical work that links current account dynamics and exchange rate regimes revolves around the issue of current account reversals to their equilibrium values. Edwards (2004) was one of the first such papers, examining how an intertwining of the current account reversals and exchange rate regimes affects real activity. The later empirical work deals more explicitly with the role of regimes in current account adjustments, mostly providing evidences in support of assertion that floating regimes are benefitial for external stability. The notable examption is a study of Chinn and Wei (2013), which could not find robust evidence supporting the notion that current account adjusts at higher pace under the flexible exchange rate regimes. Also, in their previous research based on SEE countries, Grubišić and Kamenković (2013) established that all countries in the region have had huge current deficit in precrisis period regardless exchange rate regime. As a consequence, all of the selected SEE countries have had significant capital inflow, but since crisis began, FDI have been more modest. The Table 1 provides an overview of studies dealing with effects of exchange rate regimes on current account.

Table 1: Overview of the selected previous studies which analyze effects of exchange rate regimes on current account

\begin{tabular}{|c|c|c|c|}
\hline Work & Sample & Approach & $\begin{array}{l}\text { Floating regimes are } \\
\text { benefitial for current } \\
\text { account adjustments }\end{array}$ \\
\hline Özmen (2005) & 79 countries (1993-2001) & $\begin{array}{l}\text { Cross country } \\
\text { regression }\end{array}$ & Yes \\
\hline Ghosh et al. (2008) & 151 countries (1981-2007) & Dynamic panel & $\begin{array}{l}\text { Partially, for low } \\
\text { initial imbalances }\end{array}$ \\
\hline Herrmann (2009) & $\begin{array}{l}11 \text { catching-up countries } \\
\text { from CE, EE and SE Europe } \\
(1994-2007)\end{array}$ & Dynamic panel & Yes \\
\hline Tippkötter (2010) & 171 countries (1970-2008) & Dynamic panel & Yes \\
\hline Arratibel et al. (2011) & 9 CEE countries (1995-2008) & Panel estimation & Yes \\
\hline Chinn and Wei (2013) & 170 countries (1971-2005) & Dynamic panel & No \\
\hline Pancaro (2013) & $\begin{array}{l}22 \text { industrial economies } \\
(1970-2007)\end{array}$ & \begin{tabular}{|l|}
$\begin{array}{l}\text { Panel probit } \\
\text { regression }\end{array}$ \\
\end{tabular} & Yes \\
\hline Ghosh et al. (2013) & 159 countries $(1980-2010)$ & Dynamic panel & Yes \\
\hline $\begin{array}{l}\text { Gnimassoun and } \\
\text { Coulibaly (2014) }\end{array}$ & $\begin{array}{l}44 \text { Sub Saharan Africa } \\
\text { countries }(1980-2011)\end{array}$ & Panel cointegration & Yes \\
\hline $\begin{array}{l}\text { D'Adamo and } \\
\text { Rovelli (2015) }\end{array}$ & $\begin{array}{l}14 \text { catching up countries } \\
(1998-2011)\end{array}$ & $\begin{array}{l}\text { Panel probit } \\
\text { regression }\end{array}$ & Yes \\
\hline
\end{tabular}

Source: Author's review of selected working papers 
Apart from Bussiere et al. (2004), several other papers empirically analyze the impact of fiscal balance on current account in CEE panels, mostly with clear focus on EU new member states during the EU catching up process (Herrmann and Jochem, 2005, Rahman, 2008, Schnabl and Wollmershäuser, 2013) with exemption of Aristovnik (2006b) work, which covers total sample of post-communist countries during the period 1992-2003. Empirical assessment of the fiscal and current balances relations confirmed the twin deficit hypothesis in all of these papers. Yet, the CEE-wise studies were primarily concerned with excessive rise of current account deficits during the catching-up process. For example, Aristovnik (2006b) considers that high current account deficits in the most of CEE countries were justified by the current income trailing the permanent income, while Rahman (2008) suggests that high pace of rising current deficits in the new member states relative to other developing countries can be attributed to the more developed financial markets. Some other studies that use country-by-country analysis of current account determinants also confirms positive impact of fiscal on current balance in selected CEE countries, like Urošević et al. (2012) for Czech Republic, Hungary, Poland, Romania and Serbia, and Petrović (2014) only for Serbia, both studies using the jackknife averaging estimation. On the other side, some CEE country-specific analysis fail to find evidences in support of the twin divergence (Jošić and Jošić, 2011, for Croatia, Obadić et al, 2014, for Bulgaria, Croatia, Poland and Romania). Obadić et al. (2014) provide an interesting consideration that in indirect tax-oriented systems like CEE observed twin divergence mechanics is stemming from the tax revenue loses during the current balance consolidation and imports/consumption reduction.

Similar to previous case, the empirical studies exploring effects of exchange rate regime and volatility impact on current balance are also concerned mostly with CEE new member states. Herrmann (2009) and Arratibel et al. (2011) did not employ explicitly the exchange rate regime classification as the explanatory variables but measures of exchange rate volatility, while D'Adamo and Rovelli (2015) use categorical variable that measures gradual change in exchange rate flexibility. Yet, apart from used explanatory variable, all of these papers find that higher flexibility in exchange rates is associated with lower values of current account balance.

\section{Methodology of analysis}

In order of empirical modeling of the impact of the fiscal deficit and the exchange rate at the current account balance, the model proposed by Herrmann and Jochem (2005) is used, with certain modifications and extensions, in accordance with the objectives of our research as well as the results of the existing empirical studies discussed in the literature review. 
Their model of the dynamics of the current account balance is based on the specific features of the countries of Central and Eastern Europe (CEE), which in 2004 joined the European Union, with expectations that the macroeconomic performance of their fast growing (emerging) economies would eventually converge towards the performance of the economies of developed countries, i.e. old EU members. The starting point of their model is the standard equation of "twin deficits" (all variables are expressed in relative terms, as a percentage of gross domestic product Y) as follows:

$$
c a=s-i+g b
$$

where

ca stands for current account balance; $s$ for private savings; $i$ for private investments; and $g b$ for budget balance (here a synonym for balance of consolidated state).

Herrmann and Jochem (2005) further introduced several assumptions by which determinants of private savings are defined relevant to the dynamics of the current account balance.

- The expectation of convergence of GDP per capita has a negative impact on private savings and stimulates the private sector to borrow in order to harmonize the level of spending during the period of convergence. Consequently, differential GDP per capita ( $(Y P C)$ for a given CEE country and the benchmark EU economy (in their model of Germany) as a measure of convergence is theoretically moving in the same direction as the current account balance;

- Real effective exchange rate (REER) can have both positive and negative influence on the current account balance, depending on the level of anticipation of its appreciation. In a situation of economic convergence, the appreciation is the primary expectation in terms of the dynamics of REER, as a result of productivity growth and the inflow of foreign investment capital. In case of anticipation of the appreciation of the REER, the private sector will have a tendency to save less and borrow more, with the expectation that over time the purchasing power of his income will rise, but the effects of the appreciation on the current account balance will be similar to the effects of real convergence of GDP.

- The impact of the other two determinants, the budget balance and investments, is conditioned by the expectations of the private sector on the future tax policy and level of control of capital movement. In extreme case of a complete ban on the movement of capital, investments are fully financed by domestic savings, but have no impact on the current account balance, while the movement of 
the budget and the current account balance fully coincide. The other extreme represents strict validity of the Ricardian equivalence, where the budget deficit does not affect the current account balance, because the growth of savings of the private sector in anticipation of future tax increases annual growth of the budget deficit. In the case of real situations that involve capital mobility and partial or complete absence of validity of the Ricardian equivalence, it is reasonable to expect that budget and current deficit have the same direction to a certain degree (according to the theory of "twin deficit"), and that the investments move contrary to the current deficit in the event that part of the investment capital comes through borrowing by private entities on foreign capital markets.

The resulting functional dependency of the current account balance is described by the following function:

$c a=f(d Y P C, R E E R, g b, i)$, from which an empirical model is derived with the following specification:

$$
c a_{i, t}=a_{0}+a_{1} d y p c_{i, t}+a_{2} i_{i, t}+a_{3} g b_{i, t}+a_{4} r e e r_{i, t}+v_{i}+e_{i, t}
$$

where

$d y p c_{i, t}$ is the differential of the degree of real growth of GDP of the given CEE country and the referential benchmark economy; $i_{i, t}$ share of private investments in GDP; $g b_{i, t}$ consolidated balance of state as a percentage of GDP; reer ${ }_{i, t}$ indicator of real foreign exchange rate; $v_{i}$ is a country-individual effect; $e_{i, t}$ standard error which fulfills the assumption on normal IID distribution, $e_{i, t} \sim N\left(0, \sigma^{2}\right)$.

On the other hand, the existing empirical research has indicated a number of other relevant variables that may have impact on the current account balance. The list of the most frequently used explanatory variables in empirical modeling of the current account balance and papers in which they were used are shown in Table 2. Only those explanatory variables which have been identified in four or more empirical studies have been taken into consideration. 
Table 2: The list of most frequently used explanatory variables

\begin{tabular}{|l|l|}
\hline \multicolumn{1}{|c|}{ Variable } & \multicolumn{1}{|c|}{ Author(s) in alphabetical order } \\
\hline Fiscal/government balance & $\begin{array}{l}\text { Aristovnik (2006b), Chinn, Prasad (2003), Debelle, Faruque } \\
\text { (1996), Herrmann, Jochem (2005), Petrović (2014), Rahman } \\
\text { (2008), Urošević et al. (2012) }\end{array}$ \\
\hline Relative income & $\begin{array}{l}\text { Aristovnik (2006b), Chinn, Prasad (2003), Debelle, Faruque } \\
\text { (1996), Herrmann, Jochem (2005), Petrović (2014), Rahman } \\
\text { (2008), Urošević et al. (2012) }\end{array}$ \\
\hline Terms of trade shocks & $\begin{array}{l}\text { Aristovnik (2006b), Chinn, Prasad (2003), Debelle, Faruque } \\
\text { (1996), Petrović (2014), Urošević et al. (2012) }\end{array}$ \\
\hline Real GDP growth & $\begin{array}{l}\text { Aristovnik (2006b), Chinn, Prasad (2003), Petrović (2014), } \\
\text { Rahman (2008), Urošević et al. (2012) }\end{array}$ \\
\hline REER & $\begin{array}{l}\text { Aristovnik (2006a), Aristovnik (2006b), Debelle, Faruque } \\
\text { (1996), Herrmann, Jochem (2005), Petrović (2014), Urošević } \\
\text { et al. (2012) }\end{array}$ \\
\hline Initial Net Foreign Assets & $\begin{array}{l}\text { Chinn, Prasad (2003), Debelle, Faruque (1996), } \\
\text { Petrović (2014), Rahman (2008), Urošević et al. (2012) }\end{array}$ \\
\hline Oil trade balance & $\begin{array}{l}\text { Debelle, Faruque (1996), Petrović (2014), Rahman (2008), } \\
\text { Urošević et al. (2012) }\end{array}$ \\
\hline $\begin{array}{l}\text { Trade integration / } \\
\text { openness }\end{array}$ & $\begin{array}{l}\text { Aristovnik (2006b), Chinn, Prasad (2003), Petrović (2014), } \\
\text { Urošević et al. (2012) }\end{array}$ \\
\hline Investments or FDI & $\begin{array}{l}\text { Aristovnik (2006a), Herrmann, Jochem (2005), Petrović } \\
\text { (2014), Rahman (2008), Urošević et al. (2012). }\end{array}$ \\
\hline
\end{tabular}

Source: Author's review of selected working papers

In the specification of Herrmann and Jochem (2005) empirical model there already are budget balance, relative income and private investment, so in the final specification of our empirical model terms of trade, initial net position of foreign assets, the balance of trade in oil and openness are additionally included. Also, one modification is made compared to the initial model, relative income and growth rate of real GDP are integrated into a single indicator - a differential of real GDP growth rates of the country concerned and the referential economy, in our case the EU average $\left(r g \_d\right)$. We believe that this indicator has its advantages in comparison with relative income per capita, because public and private sectors when making decisions about savings and investments are primarily guided by the general tendency economic growth, and that the average of the EU is a more relevant benchmark indicator given that the growth rates of Germany, as well as other old EU members, were mainly low in the past two decades.

Foreign direct investments are not considered as a separate variable, since they are already covered by private investment. In addition to the above-mentioned 
variables, remittances have been added to the empirical model, which can rarely be found as control variables (e.g. Rahman, 2008). The introduction of remittances is justified by the fact that in developing countries they often represent the most important item of current transfers as integral components of the current account balance, and on the other hand it is a common wisdom that a large number of migrants from CEE countries work in the Western European economies, and because of that in some of the CEE countries the share of remittances exceeds 5, and even $10 \%$ of GDP (e.g. Bosnia, Albania).

In the final specification of the model the indicator of foreign exchange rate is introduced, as a key explanatory variable, since the effect of an exchange rate on the movement of the current account balance is the subject of primary interest in our analysis. Final empirical specification of the model is presented in two versions, as a static model,

$$
c a_{i, t}=a_{0}+a_{1} d y p c_{i, t}+a_{2} i_{i, t}+a_{3} g b_{i, t}+a_{4} f x r_{i, t}+a_{5} \text { reer }_{i, t}+\sum_{j * 1}^{5} b_{j} x_{j, i, t}+v_{i}+e_{i, t}
$$

or empirically more often used dynamic AR(1) model (Urošević et al., 2012, Aristovnik, 2006b)

$$
\begin{aligned}
c a_{i, t}= & a_{0}+b_{0} c a_{i, t-1}+a_{1} d y p c_{i, t}+a_{2} i_{i, t}+a_{3} g b_{i, t}+a_{4} f x r_{i, t}+ \\
& +a_{5} \text { reer }_{i, t}+\Sigma_{j * 1}^{5} b_{j} x_{j, i, t}+v_{i}+e_{i, t}
\end{aligned}
$$

where $f x r_{i, t}$ represents the exchange rate regime, and $x_{j, i, t}$ vector of the aforementioned control variables: terms of trade, initial net position of assets, oil trade balance, openness, remittances.

The definition of exchange rate regime requires additional methodological explanation. IMF classification of de facto 8 identified exchange rate regimes, categorized in three broad groups (hard pegs, soft pegs and floating) for the purposes of our research has been reduced to two groups of the so-called "corner" solutions, or group of fixed (pegs) and floating exchange rate regimes (floating), similar to those presented in the paper Zdravković et al. (2014). As an indicator of the impact of exchange rate regime, the model includes an artificial variable $f x r$, which takes the value 1 if the country in a given year de facto pursued a policy of fixed exchange rate, or 0 in the case of floating exchange rate. More detailed descriptions and sources of data for all variables in the model are presented in Appendix 1.

Our attention is further focused on the potential qualitative differences in the direction and intensity of the impacts of key explanatory variables in the context of economic cyclicality. Excessive expansion of incoming capital flows to CEE countries during the pre-crisis period of economic expansion questions the positive direction of the connection between the fiscal balance and the current deficits, i.e. the validity of the assumption on the twin deficits. 
Cyclical growth in government revenues as a result of a huge investment activity and rapid economic growth has enabled the countries of CEE to generate minimal government deficits, even the occasional surpluses. For example, Becker et al. (2010) suggest that in most CEE countries, despite the fact that in the pre-crisis period they led pro-cyclical fiscal policy, public debt in GDP declined, indicating that the relative increase in the government deficit expressed in relation to GDP was low and relatively stable. The constantly increase in current deficit in the given period implies that the increase in investment in respect to domestic savings was a significant generator of excessive current deficit, while the nature of the impact of government balance on the dynamics of the current account is not easy to be specified unilaterally in advance.

General economic logic suggests that foreign investors and banks perceive countries with a fixed exchange rate as a less risky for investment and credit expansion, given that the exchange rate risk is minimized and virtually converted into a political risk of sudden changes in the monetary policy objectives or devaluation. Base on comparative analysis, Zdravković et al. (2014) indicate that the CEE countries with a fixed exchange rate had on average higher current account balance deficits in the last pre-crisis year (2008), but that in 2012 recorded a lower average value of the current account balance deficit in relation to the CEE countries with floating exchange rates. The possibility that impact of exchange rate regime on current account has substantially changed following the switch from expansion to recession phase during the economic cycle complicates straightforward interpretation of association between these to economic variables, similar to the case of fiscal deficit.

During the observed period some CEE countries became members of Euro area and adopted EUR: Slovenia (2007), Slovak Republic (2009) and Estonia (2011). Membership to the Euro zone should theoretically affect dynamics of macro variables, at least fiscal balance due to adopting Maastricht criteria, but in case of these three countries no breaks in data are observed. This is most likely because Slovenia and Slovak Republic became members before crisis explodes (and influenced fiscal variables), while Estonia has never run large fiscal deficits.

In the context of the discussion on qualitative changes of interaction of variables in relation to the cyclic motion, the final specification of the empirical model is further upgraded in order to test the hypothesis of distinctive impact of the fiscal balance and the exchange rate regime on the current deficit in a period prior to 2008 , i.e. 2009-2012.

The model has been upgraded based on two sub-periods analysis of exchange rate regime impact on inflation and output found in De Grauwe and Schnabl (2004), by substituting the explanatory variables with two new ones that take the value of the original variable within a given sub-period, or zero value out of the observed period. Specifically, in the case of exchange rate regime two new variables have been defined; the first of which is variable fxr_bc (bc- before crisis), which takes 
the value 1 within the period from 1999 to 2008 and 0 in other cases, and the other is variable fxr_ac (ac - after crisis) that takes the value 1 within the period from 1999 to 2008 and 0 in all other cases. In the same variables gb_bc and gb_ac are defined which substitute to the model the original variable of fiscal balance. Having applied this approach, the partial evaluation of the model has been avoided based on two sub-samples, which could result in unreliable estimation, especially in the post-crisis subsample with a small number of available observations.

\section{Empirical data and analysis}

The simplest estimation method in panel regression analysis, known as the "pooled OLS" estimation, is theoretically grounded on the restrictive assumptions that random errors are neither mutually correlated across individuals nor correlated with regressors. These assumptions further imply that between or within dimensions of the panel structure efficiency of OLS estimator is not influenced. However, these assumptions are mostly not real in economic data. The typical issue in the panel econometric analysis is potential endogeneity in the model, violating assumption of no correlation between random error and explanatory variables. In the static panel models, it is typically caused either by presence of unobserved heterogeneity or/and simultaneity in the data. The issue of unobserved heterogeneity is related to the individual-specific effects on dependent variable, which influence reliability of inference in a similar manner as the issue of omitted variable. The issue of simultaneity is related to the potential endogenous feedback from dependent variable to explanatory variables. The unobserved heterogeneity is the subject of less concern, provided by the Fixed Effects (FE) or Random Effects (RE) estimators under assumption that individualspecific effects are one-dimensional (varying only across time or only across units). The choice between these two estimators depends on the initial assumption whether the distribution of the unobserved individual-specific effects is random or fixed. On the other side, the endogeneity caused by the simultaneity is more complicated to handle using instrumental variables approach, but we can argue that at least our main explanatory variables are exogenous, especially exchange rate regime. Government balance, i.e. primary balance is mostly driven by the fiscal reaction of government to public debt accumulated and output gap (see for example Bohn, 1998), while choice of exchange rate regime is exogenous long-run outcome of the monetary policy which does not change on annual basis. However, inclusion of lagged dependent variable in panel dynamic models with individual-specific effects results in endogeneity, as lagged dependent variable is necessarily correlated with error (Wooldridge 2010, pp. 256), so least squared based estimators are inconsistent, especially if time dimension of the panel is short. The frequent solution to sort out this issue is application of Arellano-Bond (AB) GMM estimator, which is consistent even in the presence of AR components in the model. Thus, we run both FE and RE estimations of static model and GMM estimation of dynamic model. 
The empirical model was estimated on the basis of panel data on macroeconomic performance of $16 \mathrm{CEE}$ countries, 11 new EU member states and 5 countries of the Western Balkans. The analysis covers the period from 1999 to 2012, a maximum of 200 observations. All three versions of the model are estimated in two variants. The first variant is the basic model, which includes: the fiscal balance and the exchange rate regime (key explanatory variables), differential growth, the share of private investments and the real effective exchange rate. Possible econometric issue related to the variables specified in the model is collinearity that may arise because both exchange rate regime and real effective exchange rate are included; yet in the sample these variables are low correlated (correlation coefficient is only around 0.22 ).

Specification of the second variant is extended by including in the model the control variables described in the previous section. We have taken into an account that the assumption of homoscedastic random error in the panel countries is probably not realistic, so testing of significance for all three versions is based on the estimation of covariance matrix of residuals that is robust to heteroscedascity misspecification.

Other important methodological notes refer to $\mathrm{R}$ Squared and checking of consistency of Arellano-Bond GMM estimator. GMM estimation does not produce standard R Squared as an estimation output, but instead a pseudo R Squared is calculated as the square of the correlation coefficient between actual and model predicted values.

Consistency of AB GMM estimator is typically tested using the Sargan test of overidentifying restrictions and $\mathrm{AB}$ test for first- and second-order autocorrelation in the first-differenced errors. Sargan test under the assumption of homoscedastic errors has asymptotic chi-squared distribution, but in the presence of heteroscedastic errors distribution is not a priori known. As Arellano and Bond (1991) show, nonrobust Sargan test in case of heteroscedascity has overrejecting tendency, while robust Sargan test is not possible to compute. The $\mathrm{AB}$ test for first- and secondorder autocorrelation in the first-differenced errors can be computed for both homoscedastic and robust case. While non-zero correlation is expected in testing the $\mathrm{AB}$ first-order test due to construction of $\mathrm{AB}$ estimator, lack of correlation in testing the $\mathrm{AB}$ second-order test is considered as a sign that the moment conditions of $A B$ estimator are valid.

Also, because of the potential simultaneous determination of the government and the current account balance on the assumption about the twin deficits, in GMM estimation government balance is treated endogenously and it is instrumentalized. Last GMM methodological note applies to the use of the first and second lag of the dependent variable as a regressor, since the second lag also expresses statistically significant effect.

The results of estimation of regression models under (2) and (3) are shown in Table 3. 
Zoran Grubišić, Sandra Kamenković, Aleksandar Zdravković • Impact of government...

Zb. rad. Ekon. fak. Rij. • $2018 \cdot$ vol. $36 \cdot$ no. $1 \cdot 309-336$

Table 3: The results of estimation of the basic and the enlarged model

\begin{tabular}{|c|c|c|c|c|c|c|}
\hline & fel & fe 2 & rel & re2 & gmm1 & gmm2 \\
\hline \multirow[t]{2}{*}{$\mathrm{gb}$} & -0.2367 & -0.0829 & -0.245 & -0.126 & -0.1345 & -0.0256 \\
\hline & $(0.1828)$ & $(0.1578)$ & $(0.1827)$ & $(0.1469)$ & $(0.1429)$ & $(0.1003)$ \\
\hline \multirow[t]{2}{*}{ fxr } & $-0.0161 * * *$ & $-0.0141 * * *$ & $-0.0171 * *$ & $-0.0135 * *$ & $-0.0120 * *$ & $-0.0119 * *$ \\
\hline & $(0.0052)$ & $(0.0047)$ & $(0.0067)$ & $(0.0054)$ & $(0.0051)$ & $(0.0047)$ \\
\hline \multirow[t]{2}{*}{ rg_d } & -0.1835 & -0.1424 & $-0.1906^{*}$ & $-0.1695 * *$ & $-0.3717 * * *$ & $-0.2646^{* * *}$ \\
\hline & $(0.1092)$ & $(0.0879)$ & $(0.1073)$ & $(0.0797)$ & $(0.0671)$ & $(0.0573)$ \\
\hline \multirow[t]{2}{*}{$\mathrm{i}$} & $-1.0931 * * *$ & $-1.0666 * * *$ & $-1.0700 * * *$ & $-1.0405^{* * *}$ & $-0.6983 * * *$ & $-0.6963 * * *$ \\
\hline & $(0.134)$ & $(0.0869)$ & $(0.1305)$ & $(0.0875)$ & $(0.1193)$ & $(0.1001)$ \\
\hline \multirow[t]{2}{*}{ reer } & 0.0003 & 0.0005 & 0.0003 & 0.0004 & 0.0002 & 0.0004 \\
\hline & $(0.0003)$ & $(0.0004)$ & $(0.0003)$ & $(0.0004)$ & $(0.0002)$ & $(0.0003)$ \\
\hline \multirow[t]{2}{*}{ openness } & & -0.0132 & & 0.0107 & & -0.0253 \\
\hline & & $(0.0266)$ & & $(0.0232)$ & & $(0.02)$ \\
\hline \multirow[t]{2}{*}{ tot } & & $0.0013 * * *$ & & $0.0015 * * *$ & & $0.0010 * * *$ \\
\hline & & $(0.0004)$ & & $(0.0004)$ & & $(0.0003)$ \\
\hline \multirow[t]{2}{*}{$\mathrm{nfa}$} & & 0.0428 & & $0.0478^{*}$ & & 0.0065 \\
\hline & & $(0.0246)$ & & $(0.026)$ & & $(0.0216)$ \\
\hline \multirow[t]{2}{*}{ oil_bal } & & 0.2795 & & $0.4708^{*}$ & & $0.5656^{* * *}$ \\
\hline & & $(0.3089)$ & & $(0.2718)$ & & $(0.2171)$ \\
\hline \multirow[t]{2}{*}{ remit } & & 0.2531 & & 0.1494 & & 0.0792 \\
\hline & & $(0.1541)$ & & $(0.1268)$ & & $(0.0912)$ \\
\hline \multirow[t]{2}{*}{ L.gb } & & & & & $0.3852 * * *$ & $0.3709 * * *$ \\
\hline & & & & & $(0.0746)$ & $(0.0734)$ \\
\hline \multirow[t]{2}{*}{ L2.gb } & & & & & $-0.1255^{*} *$ & $-0.0853^{* *}$ \\
\hline & & & & & $(0.053)$ & $(0.0428)$ \\
\hline \multirow[t]{2}{*}{ _cons } & $0.1594 * * *$ & 0.0233 & $0.1503 * * *$ & -0.016 & $0.1022 * * *$ & 0.038 \\
\hline & $(0.0465)$ & $(0.0417)$ & $(0.0392)$ & $(0.0443)$ & $(0.0339)$ & $(0.0415)$ \\
\hline No. of Obs. & 200 & 189 & 200 & 189 & 191 & 179 \\
\hline R-Squared & 0.71 & 0.75 & 0.71 & 0.75 & 0.57 & 0.6 \\
\hline $\operatorname{AR}(1)$ & & & & & $0.0068 * * *$ & $0.0231 * *$ \\
\hline $\mathrm{AR}(2)$ & & & & & 0.3218 & 0.8734 \\
\hline
\end{tabular}

Note: Standard errors in parentheses; Pseudo R-Squared for GMM; AR(1) and AR(2) denote $\mathrm{p}$-values of $\mathrm{AB}$ test for first- and second-order autocorrelation in the first-differenced errors.

Levels of significance: $*$ if $\mathrm{p}<0.1, * *$ if $\mathrm{p}<0.05, * * *$ if $\mathrm{p}<0.01$

Source: Author's calculation based on the data given in Appendix 1 
In order to provide a deeper insight into the issues of interaction of exchange rate regime, the government and the current account balance in the context of economic cycles and the global economic crisis, we estimated the upgraded model as described in the methodological section.

Table 4: Results of estimation of the upgraded model

\begin{tabular}{|l|r|r|r|}
\hline & \multicolumn{1}{|c|}{ fe } & \multicolumn{1}{c|}{ re } & \multicolumn{1}{c|}{ gmm } \\
\hline gb_bc & -0.1306 & -0.1852 & -0.0682 \\
\hline & $(0.1672)$ & $(0.1657)$ & $(0.1146)$ \\
\hline gb_ac & 0.0658 & 0.0503 & 0.0207 \\
\hline & $(0.1112)$ & $(0.1034)$ & $(0.0986)$ \\
\hline fxr_bc & $-0.0176^{* *}$ & $-0.0167 * *$ & $-0.0183 * * *$ \\
\hline & $(0.0075)$ & $(0.0075)$ & $(0.0069)$ \\
\hline fxr_ac & 0.0063 & 0.0053 & 0.0029 \\
\hline & $(0.0123)$ & $(0.0128)$ & $(0.0098)$ \\
\hline rg_dif & -0.0921 & $-0.1232 *$ & $-0.1798^{* * *}$ \\
\hline & $(0.0751)$ & $(0.0748)$ & $(0.0605)$ \\
\hline i & $-0.9782 * * *$ & $-0.9720 * * *$ & $-0.6377 * * *$ \\
\hline & $(0.0937)$ & $(0.095)$ & $(0.0832)$ \\
\hline reer & 0.0004 & 0.0004 & 0.0003 \\
\hline & $(0.0003)$ & $(0.0004)$ & $(0.0002)$ \\
\hline No. of Obs. & 194 & 194 & 187 \\
\hline R-Squared & 0.76 & 0.76 & 0.58 \\
\hline AR(1) & & & $0.0158 * *$ \\
\hline AR(2) & & & 0.8915 \\
\hline
\end{tabular}

Note: Standard errors in parentheses; Regression coefficients for control variables are omitted; Pseudo R-Squared for GMM; AR(1) and AR(2) denote p-values of AB test for first- and second-order autocorrelation in the first-differenced errors.

Levels of significance: * if $\mathrm{p}<0.1, * *$ if $\mathrm{p}<0.05, * * *$ if $\mathrm{p}<0.01$

Source: Author's calculation based on the data given in Appendix 1

In Table 4 the results of the upgraded model are presented, estimated for the full specification, but the regression coefficients of control variables are omitted in order to make the table more transparent. 


\section{Results and discussion}

Estimation of the basic model under (2) and (3) points to several interesting results. With the exception of the real effective exchange rate, the estimated regression coefficients in the basic model have a negative sign, while additional control variables except in the case of trade integration have positive signs. The estimated direction of impact of all regressors is extremely robust in relation to the specifications and methods of estimation, while the estimated significance is robust to a lesser extent. The impact of the government balance on the current account balance is estimated negative and insignificant, contrary to the hypothesis of the twin deficits.

Furthermore, with the inclusion of the control variables, the regression coefficient of the government balance evidently loses in its intensity. The estimated impact of the fixed exchange rate regime is expected to be negative, significant and of a very robust intensity, implying that during the covered period countries with fixed exchange rates had on average lower current account balance of about 1.5 percentage points.

The negative impact of investments on the current account balance is highly expressed and expected (increase in investments by one percentage point resulted in an average reduction of the current account balance in the range of 0.6 to 1 percentage point), bearing in mind that we have previously noted that the greater part of economic activity in the observed period was financed by foreign accumulation. On the other hand, the negative impact of the differential of real growth and its statistical significance confirmed by RE and GMM estimation has led to a surprising result. According to the discussion about how a higher level of convergence leads to a strengthening of domestic savings and slowing down borrowing abroad, it was expected that countries with a slower pace of growth had lower values of the current account balance, but empirical results showed the opposite tendency, i.e. that countries with faster growth had a tendency to increase its current deficits most rapidly. This result implicitly points to the phenomenon of "overheating" of economic growth as a result of the irrationality of economic agents of the private sector, i.e. that the private sector of countries which were growing fastest had the most optimistic expectations of future growth so it invested too much and spent heavily. It should be noted that other papers which in the empirical analysis used GDP growth rate as a regressor also identified negative impact (Urošević et al., 2012, Petrović, 2014).

Estimations of the impact of other variables in the model have the expected direction, but are generally statistically insignificant except for terms of trade and oil balance. Higher values of terms of trade index indicate a better export competitiveness and a higher value of the current account balance. Similarly, it can be applied to oil balance - smaller difference in exports and imports of oil products 
implies higher values of the current account balance. The first lag of the current account balance in the dynamic specification is also significant and positive as expected due to the assumed persistence and there is an interesting finding that the second lag has negative and significant impact which indicates the probable meanreversion effect to the equilibrium value. The total explanatory power of the model measured with R-Squared is excellent and it ranges from 57 to 75 percent.

In summary, the results of initial estimation confirm the assumptions presented in our discussion about the nature of relations between the government balance and the exchange rate regime and the current account balance. The estimated insignificance of the impact of government balance on the current account balance confirms the assumption on the absence of strong links between the government and the current account balance, or rejection of the hypotheses on the twin deficits, in the case when the cyclic nature of economic developments is expressed. Moreover, a negative regression coefficient indicates that during the observed period current account balance and government balance tended to move in opposite directions.

The absence of strong links between the government and the current account deficit is not an indirect confirmation of Ricardian equivalence, since it is not caused by changes in saving, but investment expansion. However, the assumption was confirmed about the negative impact of a fixed exchange rate regime for the observed period, i.e. those countries with fixed exchange rate regimes, recorded on average lower values of the current account balance.

The results of estimation of the upgraded model confirm our hypothesis that there has been a qualitative change in the impact of exchange rate regime in the period before and after the crisis. In the pre-crisis period, the fixed exchange rate regime has a stimulating effect to foreign investors and banks, so the private sector in these countries financed its investments and consumer activities on the basis of foreign funds to a systematically higher extent than in the countries with floating exchange rates. Therefore, the CEE countries with a fixed exchange rate on average recorded current account balance of about 2 percentage points lower than the countries with floating exchange rates.

In the post-crisis period, the lack of capital inflows from abroad and the pressure on reducing balance of payments imbalances shook greatly both countries with fixed and countries with floating exchange rate, and the connection between the current account balance and the exchange rate regime has become positive as it was expected, but without statistical significance. The impact of government balance on the current account balance expectedly does not have statistical significance even in an upgraded model but there are solid indications that there is a qualitative change of connection in relation to the phases of the cycle: in the pre-crisis period it was negative and slightly more intense as compared to the initial estimation, while in the post-crisis period it was positively estimated. 
Therefore, it can be concluded that in the period of economic expansion based on international financing, the mechanism of twin deficits may be suspended to the extent that the government and the current account balance move in opposite directions. Conversely, in the phase of recession with reduced FDI where investments converge towards domestic savings, there is a tendency to re-establish the mechanism of twin deficits.

Eventually, there are three important research limitations that should be mentioned. Firstly, due to limited number of observations and huge number of explanatory variables, we avoid examination of possible differences in relations between current account, fiscal balance and exchange rate regimes on the level of country subgroups, e.g. like EU vs. non-EU member states. Secondly, we did not investigate possible non-linearities in relations or interactions with other variables which may serve as transmission channels (like public indebtedness in work of Nickel and Tudyka, 2014), again being limited by the available observations. Thirdly, we did not use structural values of current account and fiscal balance. Opposite to countries' structural fiscal balances, which are routinely computed and disclosed by many international organizations, proper methodologies for calculation of structural current balance are still under consideration and thus, its computation is quite demanding. In that sense, exploration of non-linearities in relations or subsample analysis, as well as use of structural values, remain important topics for the further research.

\section{Conclusions}

In this paper it was analyzed whether the fiscal policy and the choice of exchange rate regime might play significant role in current account determination and preservation of external stability in 16 CEE countries, during the period 1999 - 2012. The results of the analysis confirm both of our assertions: that the "twin deficit" mechanics of fiscal and current account balance co-movements may be suspended during the large fluctuation of economic activities, while floating exchange rate regimes remain beneficial tools in adjustments of current account imbalances. When expansion and recession periods are particularly analyzed, impact of government balance and exchange rate regime on current account appears to be asymmetric. In the pre-crisis period, results suggest yet insignificantly, the occurrence of "twin divergence". On the other hand, the lack of responsiveness of the current balance to exchange rate regime in post crisis period reveal that CEE countries, both with fixed and floating regimes, faced excessive accumulated current balances and were under pressure to stabilize them already in the mid-run. The results of our analysis contribute to the ongoing debate on the role of fiscal and exchange rate regimes policy in external stability in several ways. First, contrary to the panel-based studies covering similar periods and group of CEE countries, discussed in the literature section, the evidence is provided against the twin deficit 
hypothesis. Second, it was found that floating exchange rate regimes are beneficial even in case of large appreciation pressures, caused by the huge inflow of the foreign capital reflected through the impact of investments, which is contrary to the expected outcome of the Mundell-Fleming model. Eventually, our analysis indirectly indicates that excessive current imbalances were not supported by the structural fundamentals, as they were mostly driven by the cyclical factors, i.e. investment boom, also opposite to the speculations in the discussed similar papers. Whilst our econometric results are very robust to the model specifications and estimation methods, the fact that cyclically adjusted current balance was not used as the measure of external stability, puts limits to the robustness of our interpretations and conclusions. For example, correction of the imports and exports for the automatic adjustments to economic activity fluctuations may result in restoring the significance of fiscal and current balance relation. Thus, re-assessing examined issues in the framework of cyclical adjustment may give additional robustness to the results and for sure provide the basis for the future research. Taking into account summary of the results, it can be concluded that in case of the periods of economic expansions the mechanism of twin deficits is likely to be suspended making fiscal policy ineffective in controlling current account adjustments, so that the floating regimes, and monetary policy in general, remain the last line of external stability defense. Therefore, policy makers in CEE countries should consider very carefully whether shifting the monetary policy to the fixed regimes may be a reasonable decision as the catching up process is not utterly completed.

\section{References}

Akbostanc1, E., Tunç, G.I. (2002) "Turkish Twin Effects: An Error Correction Model of Trade Balance" (No. 0106), Middle East Technical University Economic Research Center Working Paper (www.econ.metu.edu.tr/ erc/2001series/0106.pdf), Ankara, Turkey.

Arellano, M., Bond, S. (1991) "Some Tests of Specification for Panel Data: Monte Carlo Evidence and an Application to Employment Equations", Review of Economic Studies, Vol. 58, No. 2, pp. 277-297, doi: 10.2307/2297968.

Aristovnik, A. (2006a) "Current Account Deficit Sustainability in Selected Transition Economies", Zbornik radova Ekonomskog fakulteta u Rijeci: Časopis za ekonomsku teoriju i praksu, Vol. 24, No. 1, pp. 81-102.

Aristovnik, A. (2006b) "The Determinants and Excessiveness of Current Account Deficits in Eastern Europe and Former Soviet Union”, William Davidson Institute Working Paper No. 827, University of Michigan, doi: 10.2139/ssrn.920507.

Aristovnik, A. (2013) "Twin Deficits and the Feldstein-Horioka Puzzle: A Comparison of the EU Member States and Candidate Countries", Actual Problems of Economics, Vol. 143, No. 5, pp. 205-214. 
Arratibel, O. et al. (2011) “The Effect of Nominal Exchange Rate Volatility on Real Macroeconomic Performance in the CEE Countries", Economic Systems, Vol. 35, No. 2, pp. 261-277, doi: 10.1016/j.ecosys.2010.05.003.

Becker, T. et al. (2010) "Whither Growth in Central and Eastern Europe?", Policy Lessons for an Integrated Europe, Bruegel Blueprint 11.

Blanchard, O., Perotti, R. (2002) "An Empirical Characterization of the Dynamic Effects of Changes in Government Spending and Taxes on Output", The Quarterly Journal of economics, Vol. 117, No. 4, pp. 1329-1368, doi: 10.1162/ 003355302320935043.

Bluedorn, J., Leigh, D. (2011) "Revisiting the Twin Deficits Hypothesis: The Effect of Fiscal Consolidation on the Current Account", IMF Economic Review, November 2011, Vol. 59, No. 4, pp. 582-602, doi: 10.1057/imfer.2011.21.

Bohn, H. (1998) "The Behavior of U.S. Public Debt and Deficits", The Quarterly Journal of Economics, Vol. 113, No. 3, pp. 949-963, doi: 10.1162/003355398 555793.

Bussiere, M., Fratzscher, M., Muller, G. (2004) "Current Account Dynamics in OECD and EU Acceding Countries - an Intertemporal Approach", European Central Bank, Working Paper Series No. 311 - February 2004. Available at SSRN: https://ssrn.com/abstract $=515074$.

Calvo, G. A., Reinhart, C. M. (2002) "Fear of Floating", The Quarterly Journal of Economics, Vol. 117, No. 2, pp. 379-408, doi: 10.1162/003355302753650274.

Ca'Zorzi, M., Chudik, A., Dieppe, A. (2012) "Thousands of Models One Story: Current Account Imbalances in the Global Economy", Journal of International Money and Finance, Vol. 31, No. 6, pp. 1319-1338, doi: 10.1016/j.jimonfin. 2012.02.003.

Cheung, C., Furceri, D., Rusticelli, E. (2010) "Structural and Cyclical Factors behind Current-Account Balances", OECD Economics Department Working Papers, No. 775, OECD Publishing, Paris, doi: 10.1787/5kmfkz2t4mbr-en.

Chinn, M. D., Wei, S. J. (2013) "A Faith-Based Initiative Meets the Evidence: Does a Flexible Exchange Rate Regime Really Facilitate Current Account Adjustment?", Review of Economics and Statistics, Vol. 95, No. 1, pp. 168-184, doi: 10.1162/rest_a_00244.

Chinn, M.D., Ito, H. (2007) "Current Account Balances, Financial Development and Institutions: Assaying the World Saving Glut", Journal of International Money and Finance, Vol. 26, No. 4, pp. 546-569, doi: 10.1016/j.jimonfin. 2007.03.006.

Chinn, M.D., Prasad, E.S. (2003) "Medium-Term Determinants of Current Accounts in Industrial and Developing Countries: An Empirical Exploration", Journal of International Economics, Vol. 59, No. 1, pp. 47-76, doi: 10.1016/ s0022-1996(02)00089-2. 
Corsetti, G., Müller, G. (2006) "Twin Deficits: Squaring Theory, Evidence and Common Sense", Economic Policy, Vol. 21, No. 48, pp. 598-638, doi: 10.1111/j.1468-0327.2006.00167.x.

D'Adamo, G., Rovelli, R. (2015) "The Role of the Exchange Rate Regime in the Process of Real and Nominal Convergence“, Journal of Macroeconomics, Vol. 43, pp. 21-37, doi: 10.1016/j.jmacro.2014.09.004.

De Grauwe, P., Schnabl, G. (2004) "Exchange Rate Regimes and Macroeconomic Stability in Central and Eastern Europe“" In: Euro Adoption in Central and Eastern Europe: Opportunities and Challenges, Editor: Susan Schadler, International Monetary Fund, 2005, pp. 41-58, doi: 10.5089/9781589063709. 072.

Debelle, G., Faruque, H. (1996) "What Determines the Current Account? A Cross Sectional and Panel Approach", International Monetary Fund Working Paper 58. IMF, pp. 1-42, doi: 10.5089/9781451966701.001.

Domac, I., Peters, K., Yuzefovich, Y. (2001) "Does the Exchange Rate Regime Affect Macroeconomic Performance? Evidence from Transition Economies", Policy research working paper 2642, The World Bank, Europe and Central Asia Region, doi: 10.1596/1813-9450-2642.

Edwards, S. (2004) "Thirty Years of Current Account Imbalances, Current Account Reversals and Sudden Stops" (No. w10276), National Bureau of Economic Research, doi: 10.3386/w10276.

European Commission, Monthly Bulletin (2014) "To What Extent has the Current Account Adjustment in the Stressed Euro Area Countries been Cyclical or Structural?“, January 2014, Box 5, pp. 47-50.

Forte, F., Magazzino, C. (2015) "Ricardian Equivalence and Twin Deficits Hypotheses in the Euro Area", Journal of Social and Economic Development, Springer, Institute for Social and Economic Change, Vol. 17, No. 2, pp. 148166, October, doi: 10.1007/s40847-015-0013-4.

Frankel, J. A. (1999) "No Single Currency Regime is Right for All Countries or At All Times" (No. w7338), National Bureau of Economic Research, doi: 10.3386/ w7338.

Friedman, M. (1953) Essays in Positive Economics, University of Chicago Press.

Ghosh, A. R. et al. (1997) "Does the Nominal Exchange Rate Regime Matter?" (No. w5874), National Bureau of Economic Research, doi: 10.3386/w5874.

Ghosh, A. R., Gulde-Wolf, A. M., Wolf, H. C. (2002) Exchange Rate Regimes: Choices and Consequences, Vol. 1, MIT press.

Ghosh, A.R., Terrones, M., Zettelmeyer, J. (2008) "Exchange Rate Regimes and External Adjustment: New Answer to an Old Debate", The New International Monetary System, Essays in Honor of Aleksander Swoboda. Routledge, UK.

Ghosh, A. R., Qureshi, M. S., Tsangarides, C. G. (2013) "Is the Exchange Rate Regime Really Irrelevant for External Adjustment?”, Economics Letters, Vol. 118, No. 1, pp. 104-109, doi: 10.1016/j.econlet.2012.09.010. 
Gnimassoun, B., Coulibaly, I. (2014) "Current Account Sustainability in SubSaharan Africa: Does the Exchange Rate Regime Matter?", Economic Modelling, Vol. 40, pp. 208-226, doi: 10.1016/j.econmod.2014.04.017.

Grubišić, Z., Kamenković, S. (2013) "Exchange Rate Regime and its Influence on Balance of Payments Imbalances in the SEE Countries", Post Crisis Recovery, Belgrade: Belgrade Banking Academy, pp. 84-98.

Haltmaier, J. (2014) "Cyclically Adjusted Current Account Balances", Board of Governors of the Federal Reserve System International Finance Discussion Papers. N. 1126, preceding p1, doi: 10.2139/ssrn.2536569.

Herrmann, S., Jochem, A. (2005) "Determinants of Current Account Developments in the Central and East European EU Member States - Consequences for the Enlargement of the Euro Area", Deutsche Bank Discussion Paper 32/2005.

Herrmann, S. (2009) "Do We Really Know That Flexible Exchange Rates Facilitate Current Account Adjustment? Some New Empirical Evidence for CEE Countries", Applied Economics Quarterly, Vol. 55, No. 4, pp. 295-311, doi: 10.3790/aeq.55.4.295.

Jošić, H., Jošić, M. (2011) “Dvostruki deficit ili dvostruka divergencija u Hrvatskoj?”, Zbornik Ekonomskog fakulteta u Zagrebu, Vol. 9, No. 2, pp. 1-16.

Kim, S., Roubini, N. (2008) "Twin Deficit or Twin Divergence? Fiscal Policy, Current Account, and Real Exchange Rate in the U.S.", Journal of International Economics, Vol. 74, No. 2, pp. 362-383, doi: 10.1016/j.jinteco. 2007.05.012.

Levy-Yeyati, E., Sturzenegger, F. (2005) "Classifying Exchange Rate Regimes: Deeds vs. Words", European Economic Review, Vol. 49, No. 6, pp. 1603-1635, doi: 10.1016/j.euroecorev.2004.01.001.

Nickel, C., Tudyka, A. (2014), "Fiscal Stimulus in Times of High Debt: Reconsidering Multipliers and Twin Deficits", Journal of Money, Credit and Banking, Vol. 46, No. 7, pp. 1313-1344, doi: 10.1111/jmcb.12148.

Obadić, A., Globan, T., Nadoveza, O. (2014) "Contradicting the Twin Deficits Hypothesis: The Role of Tax Revenues Composition", Panoeconomicus, Vol. 61, No. 6, pp. 653-667, doi: 10.2298/pan1406653o.

Özmen, E. (2005) "Macroeconomic and Institutional Determinants of Current Account Deficits", Applied Economics Letters, Vol. 12, No. 9, pp. 557-560, doi: 10.1080/13504850500120714.

Pancaro, C. (2013) "Current Account Reversals in Industrial Countries: Does the Exchange Rate Regime Matter", ECB Working Paper, No. 1547. Available at SSRN: https://ssrn.com/abstract=2259549.

Petrović, P. (2014) "Econometric Modeling of Serbian Current Account Determinants: Jackknife Model Averaging Approach", Industrija, Vol. 42, No. 3, pp. 41-60, doi: 10.5937/industrija42-5740. 
Rahman, J. (2008) "Current Account Developments in New Member States of the European Union: Equilibrium, Excess, and EU-Phoria", IMF Working Paper, Vol. 8, No. 92, doi: 10.5089/9781451869538.001.

Reinhart, C. M., Rogoff, K. S. (2004) "Serial Default and the 'Paradox' of Rich to Poor Capital Flows" (No. w10296), National Bureau of Economic Research, doi: 10.3386/w10296.

Schnabl, G., Wollmershäuser, T. (2013) "Fiscal Divergence and Current Account Imbalances in Europe", CESifo Working Paper No. 4108.

Tippkötter, M. (2010) "Global Imbalances and the Current Account Adjustment Process: An Empirical Analysis", (No. 1011), DIW Discussion Papers.

Urošević, B., Nedeljković, M., Zildžović, E. (2012) “Jackknife Model Averaging of the Current Account Determinants", Panoeconomicus, Vol. 59, No. 3, pp. $267-$ 281, doi: 10.2298/pan1203267u.

Van Bon, N. (2014) "Current Account and Fiscal Deficits Evidence of Twin Divergence from Selected Developing Economies of Asia", Southeast Asian Journal of Economics, Vol. 2, No. 2.

Wooldridge, J.M. (2010) Econometric Analysis of Cross Section and Panel Data, Cambridge, Massachusetts, London, England: The MIT Press, September, 2010.

Zdravković, A., Bradić-Martinović, A., Kamenković, S. (2014) "Exchange Rate Regimes and Macroeconomic Performances in Emerging European Economies", Contemporary Trends and Prospects of Economic Recovery, Nice, France: CEMAFI International, pp. 456-472. 


\title{
Utjecaj proračunske bilance i tečajnog režima na tekuću platnu bilancu tijekom gospodarskog ciklusa: dokazi iz zemalja SIE ${ }^{1}$
}

\author{
Zoran Grubišicic ${ }^{2}$ Sandra Kamenković ${ }^{3}$, Aleksandar Zdravković ${ }^{4}$
}

\begin{abstract}
Sažetak
Cilj ovog istraživanja je empirijski utvrditi utjecaj fiskalne politike i izbora deviznog tečaja na stanje tekućeg računa platne bilance u 16 zemalja srednje i istočne Europe, uzevši u obzir znatna ciklička kretanja u gospodarstvu u razdoblju između 19992012. godine. U radu je provedena panel procjena utjecaja režima deviznog tečaja $i$ fiskalne ravnoteže, kao ključnih nezavisnih varijabli, na tekući račun platne bilance. Rezultati istraživanja ukazuju kako, suprotno od hipoteze o "dvojnom deficitu", fiskalna ravnoteža ima negativan i nesignifikantan utjecaj na tekuću bilancu plaćanja. S druge strane, fiksni devizni tečaj pridonosi akumulaciji tekućih deficita, posebno tijekom godina ekspanzije. Rezultati procjene su robusni za različite specifikacije modela $i$ primijenjene metode procjene. Ukazuju na povezanost divergencije između ravnoteže tekućeg računa i fiskalne ravnoteže s fluktuacijama ekonomske aktivnosti. Naime, povećanje državnih prihoda tijekom "dobrih godina", omogućilo je dodatni fiskalni prostor vladama u smanjenju deficita, unatoč procikličkim fiskalnim politikama. Također, potvrđeno je kako u razdoblju prije krize zemlje koje koriste fiksni režim deviznog tečaja akumuliraju višu razinu tekućih deficita u usporedbi sa zemljama koje koriste fluktuirajući rě̌im deviznog tečaja, unatoč aprecijacijskim pritiscima koji proizlaze iz velikog priljeva inozemnog kapitala. Temeljem rezultata empirijske analize daju se preporuke kreatorima ekonomske politike u zemljama Srednje i Istočne Europe o koristima uvođenja fluktuirajućeg režima deviznog tečaja.
\end{abstract}

Ključne riječi: dvojni deficit, devizni tečaj, tekuća bilanca plaćanja, Srednja i Istočna Europa, panel analiza

JEL klasifikacija: F32, C23, E32, E62

1 Ovaj rad je dio istraživačkih projekata pod šiframa III47009, Evropske integracije i društvenoekonomske promene privrede Srbije na putu ka EU, voditelj projekta: prof. dr. Božo Drašković i OI179015, Izazovi i perspektive strukturnih promena u Srbiji: strateški pravci ekonomskog razvoja i usklađivanja sa zahtevima EU, voditelj projekta: prof. dr. Ivan Stošić, financiranih od Ministarstva prosvjete, znanosti i tehnološkog razvoja Republike Srbije.

2 Redoviti profesor. Beogradska Bankarska Akademija, Zmaj Jovina 12, 11000 Beograd, Srbija. Znanstveni interes: međunarodne financije, makroekonomija. Tel.: +381 112621 730. E-mail: zoran.grubisic@bba.edu.rs.

3 Docent. Beogradska Bankarska Akademija, Zmaj Jovina 12, 11000 Beograd, Srbija. Znanstveni interes: makroekonomija, javne financije.Tel.: +381112621730.E-mail: sandra.kamenkovic@ bba.edu.rs.

4 Istraživač asistent. Institut ekonomskih nauka, Zmaj Jovina 12, 11000 Beograd, Srbija. Znanstveni interes: makroekonomija, javne financije. Tel.:+381 112623 055. E-mail: aleksandar. zdravkovic@ien.bg.ac.rs 


\section{Appendix}

Table A1: Variable definition and data sources

\begin{tabular}{|c|c|c|}
\hline Variable & Definition & Source \\
\hline Current balance to GDP & Current balance scaled by GDP & WEO, IMF \\
\hline $\begin{array}{l}\text { Government balance to } \\
\text { GDP }\end{array}$ & $\begin{array}{l}\text { Gross government overall balance scaled by } \\
\text { GDP }\end{array}$ & WEO, IMF \\
\hline $\begin{array}{l}\text { Private investments to } \\
\text { GDP }\end{array}$ & Private gross capital formation scaled by GDP & WEO, IMF \\
\hline GDP growth rate & Annual change of real GDP & $\begin{array}{l}\text { WEO, IMF for } \\
\text { countries in sample, } \\
\text { ECB for EU average }\end{array}$ \\
\hline Openness to GDP & Sum of export and import scaled by GDP & WEO, IMF \\
\hline Terms of trade & Terms of trade index, base year $=2005$ & WEO, IMF \\
\hline $\begin{array}{l}\text { Real effective exchange } \\
\text { rate }\end{array}$ & $\begin{array}{l}\text { Real effective exchange rate index, } \\
\text { base year }=2005\end{array}$ & WEO, IMF \\
\hline $\begin{array}{l}\text { Exchange rate regime } \\
\text { dummy }\end{array}$ & $\begin{array}{l}\text { Takes value } 1 \text { if country in given year has fixed } \\
\text { exchange rate regime, } 0 \text { otherwise }\end{array}$ & $\begin{array}{l}\text { IMF, Annual Report on } \\
\text { Exchange Arrangements } \\
\text { and Exchange } \\
\text { Restrictions; Reinhart- } \\
\text { Rogoff database on } \\
\text { exchange rate regimes }\end{array}$ \\
\hline $\begin{array}{l}\text { Net foreign asset to } \\
\text { GDP }\end{array}$ & $\begin{array}{l}\text { Sum of foreign assets held by monetary } \\
\text { authorities and deposit money banks, less their } \\
\text { foreign liabilities, scaled by GDP }\end{array}$ & WDI, World Bank \\
\hline Remittances to GDP & $\begin{array}{l}\text { Sum of personal transfers received by resident } \\
\text { households from non-resident individuals, and } \\
\text { compensation of employees who are employed } \\
\text { in an economy where they are not resident and } \\
\text { of residents employed by nonresident entities; } \\
\text { scaled by GDP }\end{array}$ & WDI, World Bank \\
\hline Oil Balance to GDP & $\begin{array}{l}\text { Difference between export and import of oil } \\
\text { scaled by GDP }\end{array}$ & WEO, IMF \\
\hline
\end{tabular}

Note: GDP according ESA 95 accounting system 